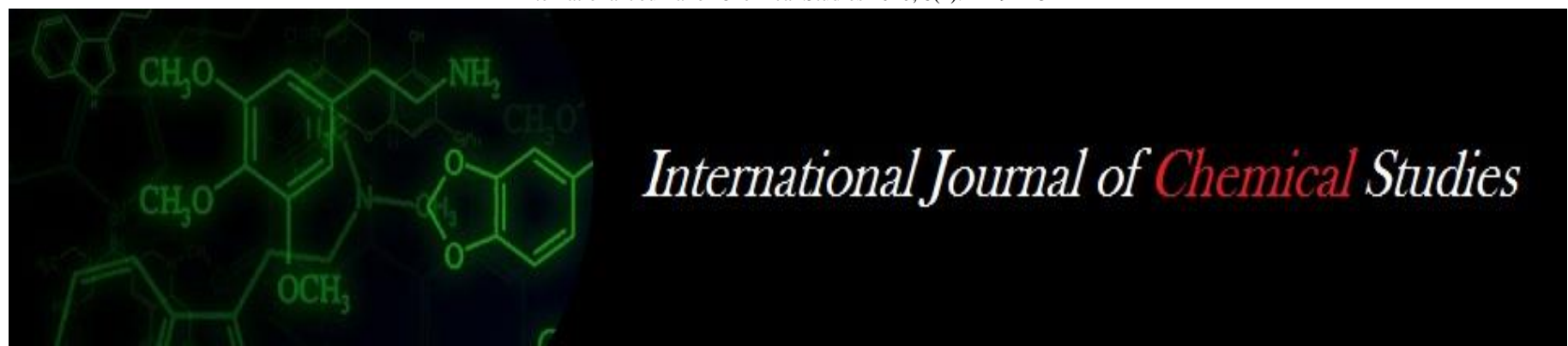

P-ISSN: 2349-8528

E-ISSN: 2321-4902

IJCS 2020; 8(1): 2429-2432

(C) 2020 IJCS

Received: 01-11-2019

Accepted: 03-12-2019

Dr. Sonali Sharma

SMS (Home Science), KVK-

Barmer, Rajasthan, India

BL Dangi

SMS (A. H.), KV K-Barmer, Rajasthan, India
Corresponding Author: Dr. Sonali Sharma SMS (Home Science), KVKBarmer, Rajasthan, India

\section{Structure and functioning of tribal area development programme (TADP) with special reference to agricultural services}

\section{Dr. Sonali Sharma and BL Dangi}

DOI: https://doi.org/10.22271/chemi.2020.v8.i1ak.8629

\section{Abstract}

Findings of the study reveal that Tribal Area Development Programme is in operation under Tribal Area Development Department since 1964. Agricultural services of the programme were implemented in seven tribal blocks of Udaipur district. For Agricultural services the funds are received from Central sponsored schemes. The programme is for tribal people below poverty line. Principal Secretary is responsible for planning, controlling and directing Tribal Area Development. Commissioner is responsible for tribal development funds and plans based on proposals received from the line departments and other agencies working in tribal areas. The Tribal Area Development Department implements its various programmes through the line departments and Agricultural services in the district are implemented by agriculture department, horticulture department and non-government organizations.

Keywords: Tribal, agriculture, programme, integrated etc.

\section{Introduction}

Tribal Development in India is a big challenge as the gap between the ideal and reality is not only woeful but widening with the passage of time. The Tribal situations in India present a varied and comparative picture and possess particular problems of economic development, as each tribe has different socio-economic situation, environment, historical experience and the extent of political articulation. On account of these factors, ethnically as well as culturally the tribes remain at different stages of socio-psychological orientation and political economic development.

The Indian constitution enjoin on the state the responsibility to promote, with special care, the education and economic interests of scheduled tribes and protect them from social injustice and all forms of exploitation. Thus their development is a special responsibility of the state.

Rajasthan is the largest state in the country having geographical area of 3,42,339 sq. km or 10.41 percent of the total geographical area of the country. The population of Rajasthan according to Census 2011 stands at about 68 million, making it the 8th most populated state in India, the population of Scheduled Tribe is 9,238,534, further in rural areas 8,693,123 tribal and 545,411 tribal in urban areas of the state, but the concentration of the ST population is greater in some parts of the state.

Attempts have been made to make the scheduled tribes to develop socially, educationally, economically, politically and culturally. For the development of tribes, various models, approaches and theories of development have been propounded in different five-year plan periods. In the Five Year Plans, the programmes for the welfare of the schedule tribes aim at:

1. Raising the productivity levels in agriculture, animal husbandry, forestry, cottage and small- scale industries etc., to improve the economic conditions.

2. Rehabilitation of the bonded labours.

3. Education and training programmes.

4. Special development programmes for women and children.

Though the efforts have been in the direction for development of tribal particularly with the creation of special multi-purpose tribal blocks during the second plan period however, a major break-through took place in the Fifth Five Year Plan in which a new strategy of tribal sub-plan 
for preparing micro plans for relatively valuable tribal groups requiring special attention was enunciated. But various evaluation studies on these programmes for the integrated development of the tribals have brought out the inadequacies of those programmes

With the view to bring the tribal areas or people of the country in the mainstream of economic development and accelerating the pace of socio-economic development, the State Government has made significant efforts to uplift the tribal people and started various activities for their social and economic development. A special programme, known as Tribal Area Developmental Programme (TADP) was taken up, on a pilot basis under a central sector plan scheme of the Ministry of Agriculture in 1964. Specific provisions have been made for funding the scheme targeting the well-being of the tribal people. In the programme, services were added and removed with the passage of time. At present it focuses on two schemes:

1. Maharashtra Pattern: Sanctioned schemes in this pattern includes animal husbandry, irrigation, education and related schemes, training programmes, ayurvedh, road and bridge construction, electricity, drinking water planning and general planning.

2. Special Central Help: The schemes include agriculture and related services, irrigation and general services.

Special Central Assistance is given to States/UTs to supplement their efforts in tribal development through Tribal Sub-Plan. This assistance is basically meant for familyoriented income-generating schemes in the sectors of agriculture, horticulture, minor irrigation, soil conservation, animal husbandry, forests, education, cooperatives, fisheries, village and small scale industries and for minimum needs programme. Grants are also given to States/UTs, under the first provision to article 275(1) of the Constitution to meet the costs of projects for tribal development and for raising the level of administration of Scheduled Area there in at par with the rest of the State/UT. Parts of the funds are utilized for setting up of Residential Schools for providing quality education to tribal students.

\section{Methodology}

Information pertaining to structure and functioning of TADP viz. basic information about the programme implementing department, its goals, organizational structure, works, schemes, programmes, provisions of department, schedule area, financial structure of TADP, linkages with other/line departments or organizations, implementation plan, monitoring, evaluation and reporting along with programme objectives and implementing departments/organization functioning. In order to collect information regarding structure and functioning of TADD and TADP, was collected from Project Office Tribal (POT), Udaipur and also collected relevant reports. Further information was also collected from website.

\section{Result}

Structure and functioning of tribal area development programme (TADP) with special reference to agricultural services

For successful running of any programme, the organizational structure with various personnel's functioning plays an important role. Therefore it was considered essential to study the structure and functioning of Tribal Area Development Department and the programme.
Organizational structure at Tribal Area Development Department (TADD): The Tribal Area Development Departments were established in 1964 under the constitution of India scheduled V in 17 states of country, to take care of scheduled area, under the Ministry of Tribal Affairs, New Delhi. In Rajasthan state, the Principal Secretary under the chairmanship of Minister of TAD is responsible for planning, controlling and directing TADD. The Principal Secretary is assisted by Commissioner and Joint Secretary with his team. Commissioner prepares plan for tribal development funds on the basis of proposals received from the line departments and other agencies working in tribal sub plan areas. The commissioner of the zone is assisted by Additional Commissioners team and Director TRI. Additional Commissioners are supported by Project Officer tribal and all other senior personnel of government departments. The Director TRI is assisted by the office team. (Appendix III). Additional commissioners are assisted by team of personnel related to various tasks.

In Tribal Area Development Department, Udaipur, there are total 255 posts of different disciplines at various levels, out of which 152 personnel (includes supporting staff mainly \& few subject experts) are working for implementation of various Tribal Area Development Schemes/Programmes in coordination with line departments as the Tribal Area Development activities/programmes are implemted by the concerned line departments. Therefore, the agricultural and allied activities in the district are implemented by Agriculture department, Horticulture department and non-government organization of the area.

\section{Goals of the Department}

1. Integrated socio-economic development of schedule tribes.

2. Planning, coordinating, controlling and directing various schemes for over all development of scheduled area.

3. Improve the living standard of tribal people.

Provisions of Department: Department has special provisions related to schedule caste as

1. Reservation in government services.

2. Special domicile certificate for reservation.

3. Reservation of seats in lok shabha and state assembly.

Schedule area: For schedule caste development, work areas/clusters decided according to the schedule $\mathrm{V}$ are -

1. Schedule area

2. Modified Area Development approach

3. MADA Cluster Scheme Area

4. Scattered tribal scheme area

5. Saharia tribes area

Beneficiaries: Tribal (SC) below poverty line is the beneficiaries of all the services under Tribal Area Development Programme

Works: Department does various works under following heads:

- Reservation related provisions in-services, activities and facilities.

- Tribal welfare in agriculture, Irrigation and building construction.

- Availability of drinking water.

- Education sector-scholarships, hostels and trainings.

- For Self-employment ITI's courses or trainings. 


\section{Schemes-For Scheduled area}

1) Special central assistance: Schemes of Agriculture development, Horticulture Development, Development of fruit garden, Livestock Development programme, Fisheries development, Forest development (Security and livelihood) Schemes, artificial insemination, facilitating with electricity on wells, providing pump set, drip and sprinkle set, constructing anicut and water shades, renovation of canals, tribals self-employment schemes, adjoining roads with necessary buildings i.e. schools and hospitals

2) Tribal Development Plans: hostels, sports and games, hostel cum schools, Aanganwadi, paid hostel, honoring rank holding students, economic assistance for college education, economic assistance for higher education, distributing scooty and cycles to girls, controlling TB, distributing micronutrients, training for industrializing and training by food craft institute. All schemes are under two types of activities

1) Community development schemes

2) Individual beneficiaries schemes.

Financial Structure: The department receives funds under various heads. As per the provisions of financial assistance along with the purpose of use is as follows-

1. Constitution Article 275 (I): For construction

2. Special central assistance: For BPL and ST individual beneficiary development.

3. Tribal welfare fund: For Education and Hostels

4. Central sponsored scheme (CSS): Provision of 50 percent financial assistance by central and state governments both for organizing trainings and other extension activities

Funding and implementation plan: The State Government has separate Ministry for tribal welfare and development. There is a provision of Scheduled Tribe Advisory Council for review and suggestion on the implementation of the schemes. At the administrative level, one Principal Secretary to the Government has been entrusted with the responsibility of tribal area development, who is responsible for coordination, review and monitoring and policy matters. Some of the activities are undertaken with the special central assistance component, in the budget controlled by the Tribal Area Development Commissioner for benefit to the tribal people of the scheduled area with financial allocations and target to benefit through various schemes.

For welfare of tribal community of scheduled areas, various programmes and schemes are being implemented by the State Government through the funds made available under special central assistance, centrally sponsored schemes and state plan schemes. The funding is made as token of commitment to the constitutional provisions as well as to socio-economic upliftment of the people residing in scheduled areas for which Tribal Sub-plan has been prepared. The programmes and the schemes are routed through the budget provisions assigned to Tribal Area Development Commissioner as well as in the departmental budget of line departments. In addition to administering the funds provided to TAD Department, Tribal Area Development Commissioner is also responsible for coordinating the activities from all the sources to avoid duplicacy and avoid wasteful expenditure.

Linkages with line departments or organizations: There are innumerous schemes under execution for development of scheduled tribes in scheduled area. The TAD Department releases the budget to various line departments or organizations of the district involved in implementation of similar activities. In Udaipur, TADP programmes/scheme are implemented by departments of Agriculture, Horticulture, Irrigation, Animal Husbandry, fisheries, Education, Electricity, PWD, PHD, Health along with respective Panchyat Samities and NGO-BAIF.

Monitoring: Monitoring of programme is done in terms of personnel and budget level in services of TADP by Commissioner and Project officer Tribal Area Development Department. The mode of monitoring is the progress based on targets achieved, the amount utilized and the number of persons benefited through the efforts of line departments.

Evaluation: Evaluation of the TADP is done by Tribal Research Institute (TRI) located in respective areas. In Udaipur district TRI take care of evaluation work.

Programme objective and implementation of the Agricultural services by the line departments

1. To reduce drudgery and saving time by providing improved agriculture tools and implements.

2. To raise economic level of tribal families/individuals through Fruit Plantation scheme/Agriculture Implements and Tools Distribution scheme/ Vegetable Development programme/Development of Whole (Agriculture) Tribal Villages/Barren Land Development through Jatropha Plantation/Livestock Development centre.

3. To develop tribal community by information provision through extension, training, environment and life style.

Agriculture Department and Horticulture Department: In these departments at district level, Deputy Director is the head of the department, responsible for implementation of programme with the assistance by Joint Director, Agriculture Officer (AO), Assistant Agriculture Officer (AAO) and Supervisor at the lowest order. The main responsibility of actual implementation of the service i.e. selecting and contacting the beneficiaries and providing the benefits related to the service from time to time, transfer of technology, execution of the programme in accordance with directors and guidelines of the scheme is soul responsibility of the grass root level field functionary i.e. Supervisor (a multipurpose extension worker) under the guidance and supervision of AAO. Supervision and monitoring is done by AAO and all other functionaries up to Deputy Director. One supervisor is responsible for coverage of programme in two and half gram panchyat. On every Thursday supervisor stays at headquarter and in rest of the days visits the field for implementation of activities in various villages.

For Agriculture activities implemented by Agriculture department in Tribal area, the budget provision was of 44.71/-lakh and 950 beneficiaries were benefitted by Agriculture Implements and Tools Distribution service in the year 2009-2010. In Horticulture Development, 907 beneficiaries were benefitted by vegetable cultivation with the budget of 22.76/- lakh in the year 2009-2010.

BAIF (Udaipur): BAIF is an NGO, the Chief Programme Coordinator is the head, who coordinate all the work in Udaipur, assisted by additional Chief Programme Coordinator. There is also a Joint Finance Coordinator who is responsible for all the financial work. At the middle of the 
chain is Senior Programme Coordinator with manger HRD, mainly responsible for implementation of the tribal development activities in the selected area and assisted by Programme Officer and Area Programme Officer at field level.

For Tribal development activities the BAIF was provided a budget of `44.58/-lakh for aonla cultivation, `20.15/-lakh for Jatropha plantation, ' 4.35 /-lakh for Livestock Development and 57.99/-lakh for Development of Whole (Agriculture) Tribal Villages, for the year 2009-2010. The activities of aonla cultivation, Jatropha plantation, Livestock Development and Development of whole (Agriculture) Tribal village benefitted-1235, 927, 2629 and 1008 beneficiaries respectively.

Reporting: The departments or organizations of implementing area report the programme achievements with budget utilization in terms of target and beneficiaries reached along TRI and Tribal Area Development Department.

\section{References}

1. A Reference Annual India. Publications DivisionMinistry of Information and Broadcasting (Government of India), 2015, 86.

2. Annual Administrative Report. Published by Tribal Area Development Department (Government of Rajasthan), 2011-2012.

3. Bedi MS. Tribal Development in Rajasthan. Himanshu Publication, Udaipur, 1995, 6. 